\title{
Inhibition Of TNF- $\alpha$ Release by D : B- Friedo - Olean -5- En- 3a -Ol in Human Monocytes
}

\section{Andriamampianina Tianarilalaina Tantely, MSc Randrianavony Patricia,, PhD}

Laboratoire de Pharmacologie Générale, de Pharmacocinétique et de

Cosmétologie, Faculté des Sciences, Université d’Antananarivo, MADAGASCAR

\section{Rasoanaivo Herilala Lea, PhD}

Laboratoire de Chimie des Substances Naturelles et de Chimie Organique

Biologique, Faculté des Sciences, Université d'Antananarivo, MADAGASCAR

\section{Pr Randimbivololona Fanantenanirainy, PhD}

Laboratoire de Pharmacologie Générale, de Pharmacocinétique et de Cosmétologie, Faculté des Sciences, Université d’Antananarivo, MADAGASCAR

\section{Abstract}

This study was focused on the release of TNF- $\alpha$ by cultured monocytes of human blood in the absence and presence of D : B Friedo olean - 5 -en- $3 \alpha$-ol (DBFO). The human monocytes were isolated from the peripheral blood mononuclear cells (PBMC). The release of TNF- $\alpha$ by monocytes was induced by the addition of lipopolysaccharide (LPS) to the culture medium. ELISA Sandwich's method was used to the dosing of TNF$\alpha$ concentration.

The release of TNF- $\alpha$ is inhibited by DBFO. In the absence of DBFO, TNF$\alpha$ concentration is $3.86 \mathrm{ng} / \mathrm{ml}$ versus $3.77 ; 3.2 ; 2.79$ and $0.89 \mathrm{ng} / \mathrm{ml}$ in the presence of DBFO at concentrations $1,3,10$ and $30 \mu \mathrm{g} / \mathrm{ml}$ respectively ( $\mathrm{p}$ $<0.05)$.

Keywords: TNF- $\alpha$ - Monocytes - Lipopolysaccharide (LPS) -D:B-friedoolean-5-en-3 $\alpha$-ol (DBFO)

\section{Introduction}

The presence of antigens and damaged cells, cause inflammation, a physiological process of the body defense (Schoroderet M., 1992). This 
reaction is intended to eliminate the phlogogenic agent and repair the tissue damage (Weill B. et al., 2003).

The presence of antigens in the organism activates the resident cells in connective tissues which release pro-inflammatory mediators such as histamine and cytokines including TNF- $\alpha$ (Williams C.M.M and Galli S.J., 2000; Weill B. et al., 2003). These pro-inflammatory mediators recruit monocytes from the bloodstream to the site of inflammation (Descamps Latscha B. and Witko -Sarsat V., 1996; Eming S.A. et al., 2007).

Andriamampianina T.T. et al. (2015) reported the anti-inflammatory activity of D: B- Friedo - olean -5 -en- $3 \alpha$-ol (DBFO) in vivo. This activity could be due to the inhibition of the release of TNF- $\alpha$ (Fiebich B.L. et al., 2001; Min- Hsiung P. et al., 2016).

Therefore, this study is aimed to investigate the DBFO activity on the release of TNF- $\alpha$ induced experimentally in vitro by exposing monocytes to lipopolysaccharide (LPS). ELISA Sandwich was used to dose the concentration of TNF- $\alpha$ released.

\section{Materials and methods:}

The effect of DBFO on the release of TNF- $\alpha$ by monocytes exposed to LPS was investigated by dosing TNF- $\alpha$ in the absence and presence of DBFO using ELISA Sandwich.

\section{Isolation of monocytes}

The blood was collected from human healthy donors in heparinized tubes and diluted with RPMI 1640 (Lonza BioWhittaker ${ }^{\circledR}$ ) (v/v). Afterwards, $30 \mathrm{ml}$ of this blood were put in a $50 \mathrm{ml}$ propylene tube containing $15 \mathrm{ml}$ of polyfluorocarbon liquid (Ficoll@) (MSL Eurobio 2000). The mixture blood - Ficoll ${ }^{\circledR}$ was centrifuged at $600 \mathrm{~g}$ for $20 \mathrm{~min}$ at room temperature (Cosma A. and Allgayer S., 2007). After centrifuging, the supernatant was removed and the interphase containing the PBMC was aspirated and transferred into a $50 \mathrm{ml}$ propylene tube.

This interphase was rinsed with $10 \mathrm{ml}$ of RPMI 1640 and centrifuged at $200 \mathrm{~g}$ for $15 \mathrm{~min}$ at room temperature. After removing the supernatant, the pellet was rinsed with $10 \mathrm{ml}$ of RPMI 1640 and centrifuged under the same conditions. The final supernatant was discarded and the cells were suspended in $1 \mathrm{ml}$ of RPMI (Cosma A. and Allgayer S., 2007 ; Vogel H. G. et al., 2008).

The cell suspension was diluted to 1/10 with a mixture of RPMI 1640 - Eosin (95: 5). The Eosin was used to differentiate live cells, which were counted with a Malassez cell of $1 \mu$ to determine the proportion of monocytes and lymphocytes in PBMC (Raulf - Heimsoth M., 2008). 
The cell culture was performed in a 48 well plate in which RPMI 1640 was added as culture medium. Two hundred microliters of suspension containing $6.66 \times 10^{6}$ PBMC were added to each well. The plate was incubated for 1 hour at $37^{\circ} \mathrm{C}$, with an $85 \%$ humidity, in the presence of $5 \%$ $\mathrm{CO}_{2}$. At the end of this period, the monocytes adhered at the bottom of the well. The non- adherent cells were removed, and the plate was rinsed twice with RPMI 1640 to ensure complete removal. The adherent monocytes were suspended in RPMI 1640 and counted using a cell Malassez of $1 \mu$ l (Wahl L.M. et al., 2005; Menck K. et al., 2014).

\section{Effect of DBFO on the release of TNF- $\alpha$ by monocytes}

Monocytes were cultured in RPMI 1640 supplemented with $0.2 \%$ of NHS (normal human serum), $2 \mathrm{mM}$ of glutamine and $1 \%$ of penicillinstreptomycin Sigma Aldrich ® $(100 \mathrm{UI} / \mathrm{ml}: 100 \mu \mathrm{g} / \mathrm{mL})$ (Adib-Conquy M. and Cavaillon J.M., 2002). They were divided into 6 sets of 8 wells of $200 \mu l$ per well. The first set containing monocytes only was used as negative control, while the second containing monocytes and LPS at a concentration of $1 \mathrm{ng} / \mathrm{ml}$ served as a positive control (Gutsmann T. et al., 2001; AdibConquy M. and Cavaillon J.M., 2002). The well of the last 4 sets were containing monocytes and LPS. DBFO was added in a concentrations of 1 , 3,10 and $30 \mu \mathrm{g} / \mathrm{ml}$ respectively. The plate was incubated for 24 hours at 37 ${ }^{\circ} \mathrm{C}$ with an $85 \%$ humidity and with $5 \%$ of $\mathrm{CO}_{2}$. At the end of this period, the supernatants were aspirated and transferred to an ELISA plate for TNF- $\alpha$ dosage (Cloëz - Tayarani I. et al., 2003).

\section{Dosage of TNF- $\alpha$}

The concentrations of TNF- $\alpha$ in the supernatants were determined by sandwich ELISA using a reactionnal kit DuoSet ${ }^{\circledR}$ ELISA Development System (R $\alpha \mathrm{D}$ Systems Minneapolis, MN) (Okubo A. et al., 1990 ; Chung C.H. et al., 2015).

To fix the first monoclonal antibody, $100 \mu \mathrm{l}$ of ELISA buffer "capture antibody" prepared in Phosphate buffered saline (PBS) were added into each well of the plate ELISA (NUNK, 96 well). The plate was incubated at room temperature for 18 hours and washed 3 times with a buffer made of $0.05 \%$ Tween 20 prepared in PBS, to remove the excess antibody. One hundred $\mu$ l of BSA 1\% (bovine serum albumin) prepared in PBS (v:v) were added into each well. The plate was incubated at room temperature for one hour, then emptied.

A standard range of recombinant TNF- $\alpha$ was prepared. Eight tubes were used. The first tube contained the reagent diluent only, made of $1 \%$ BSA prepared in PBS. The last 7 tubes contained the recombinant TNF- $\alpha$ at concentrations ranging from $1000 \mathrm{pg} / \mathrm{ml}$ to $15.6 \mathrm{pg} / \mathrm{ml}$ with a geometric 
dilution of rate 2 in the reagent diluent. The culture supernatants of monocytes were diluted to $10^{\text {th }}$. The standard range and the samples were deposited in duplicate in a volume of $100 \mu \mathrm{l}$ per well. Then the plate was incubated at room temperature for 2 hours and washed 3 times with the buffer, after the incubation period.

The solution of the second antibody containing biotin was distributed in a volume of $100 \mu \mathrm{l}$ per well. The plate was then incubated at room temperature for 2 hours and washed 3 times after the incubation.

The streptavidin - HRP ${ }^{\circledR}$ used for recognizing biotin was distributed into each well in a volume of $100 \mu \mathrm{l}$. The plate was incubated for 20 minutes and afterwards washed 3 times. The substrate solution was distributed in a volume of $100 \mu \mathrm{l}$ per well and gave a blue coloration. One hundred $\mu \mathrm{l}$ of $3 \mathrm{~N}$ $\mathrm{HCl}$ solution was then added to each well to stop the color reaction.

Fifteen minutes after the addition of $\mathrm{HCl}$, the optical density (OD) of the content of each well was read with a spectrophotometer (ELISA reader DYNEX) at $\lambda=450 \mathrm{~nm}$. The concentration of TNF- $\alpha$ in the sample was determined according to the standard range.

\section{Expression and analysis of results}

The concentration of TNF- $\alpha$ released was expressed as mean \pm standard error of mean (s.e.m.). Student " $\mathrm{t}$ " test was used to compare the means. Differences were considered as significant with a $\mathrm{P}<0.05$.

\section{Results}

\section{Isolation of monocytes}

$5 \times 10^{3}$ monocytes per microliter, or $1 \times 10^{6}$ monocytes in $200 \mu \mathrm{l}$ was noted after counting the cultured cells, indicating that the whole culture medium contains $85 \%$ of lymphocytes and $15 \%$ of monocytes.

\section{Effect of DBFO on the release of TNF- $\alpha$}

In the absence of DBFO and LPS, human monocytes don't release TNF- $\alpha$. The stimulation of monocytes by LPS induces the release of TNF- $\alpha$ in the medium. The addition of DBFO in increasing concentration in the culture medium containing monocytes and LPS, decreases the concentration of TNF- $\alpha$ released.

In the presence of $1 \mathrm{ng} / \mathrm{ml}$ of LPS, the concentration of TNF- $\alpha$ released by these monocytes is equal to $3.86 \mathrm{ng} / \mathrm{ml}$. The addition of DBFO at concentrations $1,3,10$ and $30 \mu \mathrm{g} / \mathrm{ml}$ reduced the concentration of TNF- $\alpha$ released to 3.77, 3.2, 2.79 and $0.89 \mathrm{ng} / \mathrm{ml}$ respectively $(\mathrm{p}<0.05)$ (Figure 1 ). 


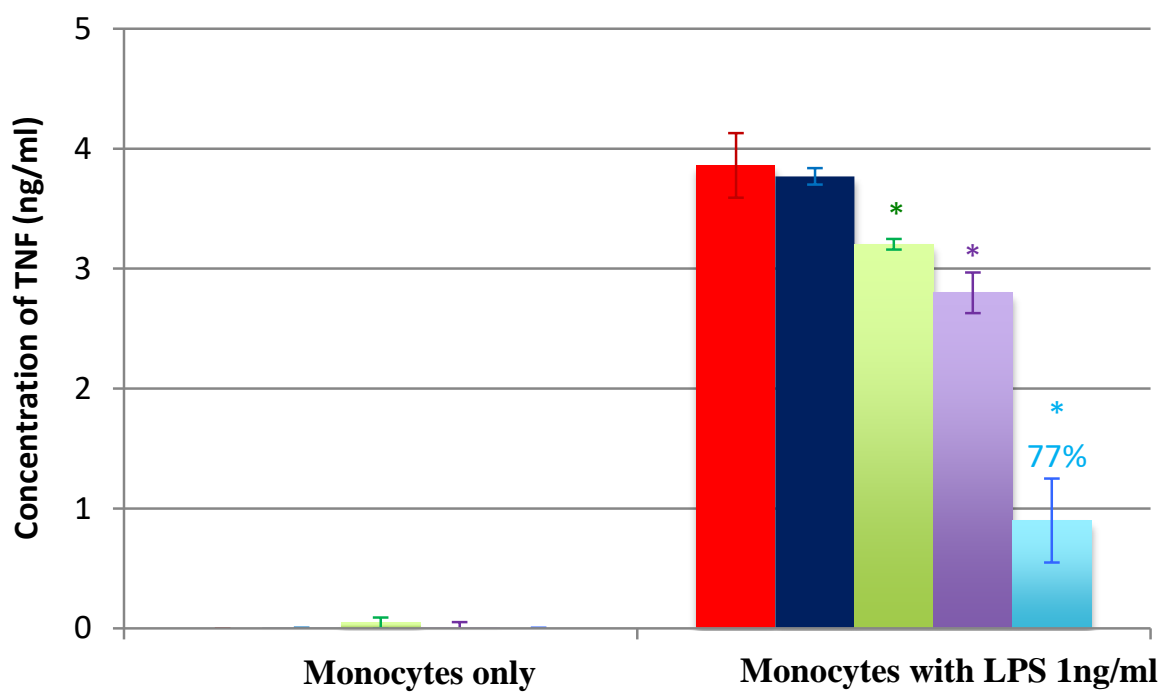

Figure 1. Variation or the concentration of TNF $-\alpha(\mathrm{ng} / \mathrm{mL})$ released by human monocytes cultured in absence of LPS, in presence of LPS - and with DBFO added at concentrations of $=1,-3,-10$ and $-30 \mu \mathrm{g} / \mathrm{mL}$ ( $\bar{x} \pm$ s.e.m., $\left.\mathrm{n}=16,{ }^{*} \mathrm{p}<0.05\right)$.

\section{Discussion:}

This work was conducted to study the effect of DBFO on the release of TNF- $\alpha$ by monocytes of human blood in vitro. Lipopolysaccharide (LPS) was used to stimulate the release of TNF- $\alpha$ by monocytes (Gutsmann T. et al, 2001 ; Adib-Conquy M. and Cavaillon J.M., 2002).

Shockman G. D. and Barrett J. F. (1983) reported that lipopolysaccharide which is a constituent of the membrane of E. coli contains a polyosidic fraction recognized as an antigen by monocytes. LPS fragment carries an antigen $\mathrm{O}$. Associated with lipid A, it binds to the membrane receptor TLR-4 (Toll - like receptor 4) of monocytes (Reeves P., 1995 Janeway C.A. et al., 2009). This interaction sends a signal to the cell nucleus and activates the nuclear transcription factor which induces the release of TNF- $\alpha$ out of monocytes (Miller S.I. and Ernst R.K., 2005).

However, in the presence of increasing concentrations of DBFO, this release of TNF- $\alpha$ by monocytes decreases. Two hypothesis could be advanced to explain this result. Either the DBFO would inhibits TNF- $\alpha$ synthesis by preventing the inductor (LPS) to bind to the monocyte membrane receptor (Nijland R. et al., 2014), or DBFO would inhibit the release of TNF- $\alpha$ by the monocytes (Kirchner S. et al., 2004).

It was reported that Hispidol, a triterpenoids isolated from Ponciri Immaturus (Shin E.M. et al, 2010) and Betulin from Boswellia serrata inhibit the TNF- $\alpha$ release from monocytes in vitro (Dzubak P. et al., 2006). On the other hand, DBFO isolated from Cladogelonium madagascariense Leandri, belongs to triterpenoids family and inhibits inflammation evoked by 
carrageenan in mice (Andriamampianina T.T. et al., 2015). It could be advanced that the activity of DBFO, in inhibiting the TNF- $\alpha$ release from human monocytes cell, could be due to its chemical nature.

\section{Conclusion}

The DBFO isolated from Cladogelonium madagascariense Leandri inhibits TNF- $\alpha$ released by monocytes stimulated with LPS in vitro.

\section{References:}

1. Adib-Conquy M. and Cavaillon J.M. Gamma interferon and granulocyte/monocyte colony-stimulating factor prevent endotoxin tolerance in human monocytes by promoting Interleukin-1 receptorassociated kinase expression and its association to MyD88 and not by modulating TLR4 expression. J. Biol. Chem., 277: 27927-27934, 2002.

2. Andriamampianina T.T., Randrianavony P., Randrianarivelo F.H., Rasoanaivo L.H., Wadouachi A., Lidwine R., Connolly J.D., Raharisololalao A. and Randimbivololona F. D:B-friedo-olean-5-en$3 \alpha$-ol isolated from Cladogelonium madagascariense Leandri (EUPHORBIACEAE) extracts and its anti-inflammatory activity in mice. J. Pharmacogn. Phytochem., 4 (4): 185-191, 2015.

3. Chung C.H., Fan J., Lee E.Y., Kang J.S, Lee S.J., Pyagay P.E., Khoury C.C., Yeo T.-K., Khayat M.F., Wang A. and Chen S. Effects of Tumor Necrosis Factor- $\alpha$ on podocyte expression of monocyte chemoattractant protein-1 and in diabetic nephropathy. Nephron Extra 5:1-18, 2015.

4. Cloëz-Tayarani I., Petit-Bertron A.F., Venters H.D. and Cavaillon J.M. Differential effect of serotonin on cytokine production in lipopolysaccharide-stimulated human peripheral blood mononuclear cells: involvement of 5-hydroxytryptamine2A receptors. Int. Immunol., 15 (2): 233-240, 2003.

5. Cosma A. and Allgayer S. PBMC purification using Ficoll. Clinical cooperation group immune monitoring version 1: 1-3, 2007.

6. Descamps-Latscha B. and Witko-Sarsat V. Cytokines proinflammatoires et cellules phagocytaires. Rev. Fr. Allergol., 36: 310314, 1996.

7. Dzubak P., Hajduch M., Vydra D., Hustova A., Kvasnica M., Biedermann D., Markova L., Urban M. and Sarek J. Pharmacological activities of natural triterpenoids and their therapeutic implications. Nat. Prod. Rep. 23 : 394-411, 2006. 
8. Eming S.A., Krieg T. and Davidson J.M. Inflammation in wound repair: molecular and cellular mechanisms. J. Invest. Dermatol., 127: 514-525, 2007.

9. Fiebich B.L., Heinrich M., Hiller K.O. and Kammerer N. Inhibition of TNF-alpha synthesis in LPS-stimulated primary human monocytes by Harpagophytum extract. Phytomed. 8 (1): 28-30, 2001.

10. Gutsmann T., Müller M., Carroll S.F., MacKenzie R.C., Wiese A. and Seydel U. Dual role of lipopolysaccharide (LPS)-binding protein in neutralization of LPS and enhancement of LPS-induced activation of mononuclear cells. Infect. Immun., 69 (11): 6942-6950, 2001.

11. Janeway C.A., Murphy K., Travers P. and Walport M. La reconnaissance de motifs moléculaires dans le système immunitaire inné. Immunobiologie Ed. De Boeck, Bruxelles, Chap. 2: 53-60, 2009.

12. Kirchner S., Holler E., Haffner S., Andreesen R. and Eissner G. Effect of different tumor necrosis factor (TNF) reactive agents on reverse signaling of membrane integrated TNF in monocytes. Cytokine., 28: 67-74, 2004.

13. Menck K., Behme D., Pantke M., Reiling N., Binder C., Pukrop T., and Klemm F. Isolation of human monocytes by double gradient centrifugation and their differentiation to macrophages in tefloncoated cell culture bags. J. Vis. Exp., 9 (91), pp. 51554, 2014.

14. Miller S. I. and Ernst R. K. LPS, TLR4 and infectious disease diversity. Nat. Rev. Microbiol. 3 (1): 36-46, 2005.

15. Min-Hsiung P., Katarzyna M., Pei-Sheng L., Jia-Ching W., Chi-Tang H., Janusz P., Mehta D.S., Stohs S.J. and Vladimir B. Inhibition of TNF- $\alpha$, IL- $1 \alpha$, and IL-1 $\beta$ by pretreatment of human monocytederived macrophages with Menaquinone-7 and cell activation with TLR agonists in vitro. J. M. Food. 19 (7): 663-669, 2016.

16. Nijland R., Hofland T. and Van-Strijp J.A.G. Recognition of LPS by TLR4: Potential for Anti-Inflammatory Therapies. Mar. Drugs., 12 (7): 4260-4273, 2014.

17. Okubo A., Sone S., Singh S.M. and Ogura T. Production of tumor necrosis factor-alpha by alveolar macrophages of lung cancer patients. Jap. J. Cancer Res. 81(4):403-409, 1990.

18. Raulf-Heimsoth M. T Cell - Primary Culture from Peripheral Blood. Methods in molecular medicine: Allergy methods and protocols. Ed. M. G. Jones and P. Lympany(C) Humana Press Inc., Totowa, NJ, Chap 2 : 17-30, 2008.

19. Reeves P. Role of $\mathrm{O}$ antigen variation in the immune response. Trends in Microbiol. 3 (10) : 381-386, 1995. 
20. Schoroderet M. Pharmacologie, des concepts fondamentaux aux applications thérapeutiques. Office des publications universitaires, 2: 523-530, 1992.

21. Shin E.M., Zhou H.Y., Xu G.H., Lee S.H., Merfort I. and Kim Y.S. Anti-inflammatory activity of hispidol A 25-methyl ether, a triterpenoid isolated from Ponciri Immaturus Fructus. Eur. J. Pharmacol. 627 : 318-324, 2010.

22. Shockman G. D. and Barrett J. F. Structure, function and assembly of cell walls of Gram negative bacteria. Ann. Rev. Microbiol., 37 : pp 501, 1983.

23. Vogel H.G., Vogel W.H., Shölkens B.A., Sandow J., Müller G. and Vogel W.F. Drug Discovery and Evaluation: Pharmacological Assays, Ed. Springer Verlag (Germany), Chap 15: pp. 1953, 2008.

24. Wahl L.M., Wahl S.M., Smythies L.E. and Smith P.D. Isolation of human monocyte populations. Current Protocols in Immunology. Ed. John Wiley \& Sons (New York), Unit 7.6A: 1-10, 2005.

25. Weill B., Batteux F. and Dhainaut J. Maladie auto-immune. Immunopathologie et réactions inflammatoires. Ed. De Boeck Université (Paris), Chap. 2: 12-23, 2003.

26. Williams C.M.M and Galli S.J. The diverse potential effector and immunoregulatory roles of mast cells in allergic disease. J. Allergy Clin. Immunol., 105: 847-859, 2000 